\title{
Penerapan Model Inkuiri Terbimbing dengan Multimedia untuk Meningkatkan Hasil Belajar IPA Tema 6 tentang Panas dan Perpindahannya pada Siswa Kelas V SD Negeri 1 Kebulusan Tahun Ajaran 2018/2019
}

\author{
Wahyu Retnoningsih ${ }^{1}$, Tri Saptuti Susiani ${ }^{2}$, Muh. Chamdani ${ }^{3}$ \\ 1,2,3 Universitas Sebelas Maret \\ retnowahyu12@gmali.com
}

\section{Article History}

accepted 01/10/2019

approved 01/11/2019

published 01/12/2019

\begin{abstract}
This study aimed to improve the learning outcomes of science with theme 6 about heat and its movement in grade $V$ students through the application of guided inquiry models with multimedia. This research was collaborative Classroom Action Resreach (CAR) carried out in three cycles. The data used were quantitative data and qualitative data. The subjects of this study were teacher and grade V students in SD Negeri 1 Kebulusan in Academic Year 2018/2019. Data collection techniques used observation, interviews, and tests. Data validity in this study used sources and techniques triangulation. Data analysis included data reduction, data presentation, and conclusion drawing. The results of this study indicated that the implementation of guided inquiry model with multimedia could improve the learning outcomes of science with theme 6 about heat and its movement in grade $V$ students in SD Negeri 1 Kebulusan in Academic Year 2018/2019.
\end{abstract}

Keywords: guided inquiry model with multimedia, learning outcomes science

\begin{abstract}
Abstrak
Penelitian ini bertujuan untuk meningkatkan hasil belajar IPA tema 6 tentang panas dan perpindahannya pada siswa kelas lima melalui penerapan model inkuiri terbimbing dengan multimedia. Jenis penelitian ini adalah penelitian tindakan kelas kolaboratif dengan tiga siklus. Data yang digunakan adalah data kuantitatif dan data kualitatif. Subjek penelitian ini adalah guru dan siswa kelas lima di sekolah dasar negeri kebulusan tahun ajaran 2018/2019. Teknik pengumpulan data yang digunakan yaitu observasi, wawancara, dan tes. Validitas data dalam penelitian ini menggunakan triangulasi teknik dan sumber. Analisis data meliputi reduksi data, penyajian data, dan penarikan kesimpulan. Hasil penelitian ini adalah model inkuiri terbimbing dengan multimedia dapat meningkatkan hasil belajar IPA tema 6 tentang panas dan perpindahannya pada siswa kelas lima sekolah dasar negeri 1 Kebulusan tahun ajaran 2018/2019.
\end{abstract}

Kata kunci: model inkuiri terbimbing dengan multimedia, hasil belajar IPA 


\section{PENDAHULUAN}

Pendidikan merupakan suatu usaha untuk membangun kehidupan masyarakat di masa kini dan masa depan supaya memperoleh kehidupan yang lebih baik dari kehidupan di masa lalu. Pada kurikulum 2013 di SD/MI sederajat, pembelajaran dilaksanakan menggunakan pendekatan tematik-terpadu. Pembelajaran tematik merupakan pembelajaran dengan mengintegrasikan kompetensi-kompetensi dari berbagai mata pelajaran ke dalam tema dengan proses pembelajaran yang bermakna serta disesuaikan dengan perkembangan siswa (Akbar, 2016: 17). Salah satu mata pelajaran yang terintegrasi adalah IPA. Wisudawati dan Eka (2015:22) menjelaskan IPA adalah rumpun ilmu yang memilik karakteristik khusus karena mempelajari fenomena alam yang faktual baik itu merupakan kenyataan atau kejadian yang memiliki hubungan sebab akibat. IPA di dalam pembelajaran merupakan kegiatan yang dilakukan oleh siswa yang memberikan kesempatan untuk mendapatkan pembelajaran melalui pengalaman seperti observasi terhadap fenomena alam, eksperimen, dan diskusi (Sayekti, 2015: 40).

IPA bertujuan agar siswa dapat mengembangkan pengetahuan, pemahaman, dan kemampuan analisisnya terhadap lingkungan alam yang ada di sekitarnya. Pada tema 6 tentang panas dan perpindahannya, dengan indikator yaitu 3.6 menerapkan konsep perpindahan kalor dalam kehidupan sehari-hari di kelas $\mathrm{V}$ dengan ruang lingkup materi tentang hantaran panas.

Setelah melaksanakan proses pembelajaran IPA, siswa dapat memperoleh hasil belajar yang merupakan perubahan tingkah laku yang diperoleh setelah melalui proses kegiatan belajar mengajar yang selaras dengan tujuan pendidikan (Purwanto, 2014: 54). Hasil belajar ranah kognitif (revisi taksonomi Bloom) terdiri dari 6 aspek yaitu: (1) mengingat (remember), (2) memahami (understand), (3) menerapkan (apply), (4) menganalisis (analyze), (5) mengevaluasi (evaluate), (6) mencipta (create) (Krathwohl, 2002: 215; Amer, 2006: 221).

Berdasarkan observasi yang telah dilakukan oleh peneliti terhadap guru dan siswa dalam proses pembelajaran di kelas $\mathrm{V}$ di SD Negeri 1 Kebulusan, pada tanggal 31 Oktober 2018 ditemukan fakta-fakta: 1) proses pembelajaran teacher centered, 2) model yang digunakan belum memfasilitasi siswa bereksperimen, 3) metode ceramah masih mendominasi pembelajaran, 4) media kurang variatif. Selain melakukan observasi, peneliti juga melakukan wawancara kepada guru tentang kondisi siswa dan hasil belajar siswa pada pembelajaran yang biasa dilaksanakan. Berdsarkan nilai ulangan harian dari total siswa kelas $\mathrm{V} 27$ orang dengan KKM 75, ada 55\% siswa belum mencapai KKM dan 45\% siswa sudah mencapai KKM.

Siswa kelas $\mathrm{V}$ yang berusia kurang lebih 11 tahun, berdasarkan pendapat Buhler (Sobur, 2013: 131-133) termasuk dalam fase perkembangan keempat yaitu usia 9-11 tahun. Lebih lanjut Buhler menjelaskan bahwa karakteristik anak pada fase keempat yaitu mereka sudah mencapai puncak objektivitasnya, maksudnya adalah mereka sudah mampu menyelidik, mencoba, dan bereksperimen dengan rasa ingin tahu yang tinggi.

Ketika melaksanakan pembelajaran, guru memerlukan model pembelajaran sebagai pedoman dalam merencanakan pembelajaran di kelas. Salah satu model pembelajaran yang sesuai dengan karakteristik siswa kelas $\mathrm{V}$ adalah inkuiri terbimbing. Aulia, Sri \& Rudiana (2017: 1) menjelaskan bahwa inkuiri terbimbing adalah sebuah proses eksplorasi aktif menggunakan kemampuan berpikir kritis, logis, dan kreatif untuk menjawab pertanyaan-pertanyaan dengan bimbingan guru. Anam (2016: 15) menyebutkan kelebihan-kelebihan inkuiri terbimbing adalah sebagai berikut: a) real life skills, yaitu siswa belajar tentang ha-hal penting namun mudah dilakukan, b) openended topic, tema yang dipelajari memiliki sumber yang tidak terbatas, c) intuitif, imajinatif, inovatif, d) peluang melakukan penemuan dengan berbagai observasi dan eksperimen.

Agar hasil yang diperoleh lebih maksimal, model inkuiri terbimbing dapat dikombinasikan dengan multimedia. Multimedia yaitu media yang melibatkan beberapa media yang terintegrasi dalam suatu kegiatan pembelajaran (Asyhar, 2012: 45). 
Berdasarkan penelitian Husein, Lovy, dan Gunawan (2015: 223) multimedia dapat meningkatkan penguasaan konsep dan keterampilan berpikir kritis siswa.

Berdasarkan uraian di atas, dapat diambil rumusan masalah yaitu: 1) Bagaimanakah langkah-langkah penerapan model inkuiri terbimbing dengan multimedia?; 2) Apakah penerapan model inkuiri terbimbing dengan multimedia dapat meningkatkan hasil belajar IPA tema 6 tentang panas dan perpindahannya pada siswa kelas V di SD Negeri 1 Kebulusan tahun ajaran 2018/2019?

Penelitian ini bertujuan untuk: (1) Mendeskripsikan langkah-langkah penerapan model inkuiri terbimbing dengan multimedia; (2) Meningkatkan hasil belajar IPA tema 6 tentang panas dan perpindahannya pada siswa kelas $V$ di SD Negeri 1 Kebulusan tahun ajaran 2018/2019.

\section{METODE}

Penelitian ini merupakan penelitian tindakan kelas (PTK) kolaboratif. Prosedur penelitian yang digunakan adalah modifikasi dari Arikunto (2013: 137) yang setiap siklusnya terdiri dari tahap yaitu perencanaan, pelaksanaan, pengamatan, dan refleksi. Subjek dalam penelitian ini adalah siswa kelas V SD Negeri 1 Kebulusan yang berjumlah 27 siswa. Data yang digunakan adalah data kuantitatif berupa nilai tes evaluasi dan data kualitatif berupa hasil observasi dan wawancara tentang penerapan model inkuiri terbimbing dengan multimedia. Teknik pengumpulan data menggunakan observasi, wawancara, dan tes. Validitas data menggunakan triangulasi teknik dan sumber. Analisis data meliputi reduksi data, penyajian data, dan penarikan kesimpulan (Sugiyono, 2012: 247-253). Indikator kinerja penelitian ini adalah penerapan model inkuiri terbimbing dengan multimedia dalam pembelajaran melalui observasi dan wawancara sebesar $85 \%$ dan peningkatan hasil belajar IPA tema 6 tentang panas dan perpindahannya dengan jumlah siswa tuntas di atas 85\% dengan KKM 76.

\section{HASIL DAN PEMBAHASAN}

Penelitian ini dilaksanakan selama tiga siklus dengan menerapkan lima langkah model inkuiri terbimbing dengan multimedia meliputi: 1) orientasi dengan media power point text, 2) konseptualisasi dengan media power point text dan gambar/video, 3) investigasi dengan bantuan media kongkret, 4) menarik simpulan, dan 5) mendiskusikan hasil dengan power point text. Langkah-langkah tersebut merupakan simpulan langkah-langkah inkuiri terbimbing dari Sanjaya (2012: 201-205) dan Pedaste et. al. (2015: 51) yang kemudian peneliti gabungkan dengan penggunaan multimedia.

Pada siklus I, hasil observasi terhadap guru mencapai persentase $75,76 \%$. Hal tersebut menunjukkan bahwa model inkuiri terbimbing dengan multimedia belum diterapkan secara maksimal. Didukung dengan hasil wawancara terhadap guru dengan persentase $79 \%$. Berdasarkan hal tersebut, dapat diketahui bahwa masih terdapat beberapa kendala yang dialami guru dalam menerapkan langkah-langkah model sehingga persentase ketuntasan jumlah siswa baru mencapai 75,93\%. Dari hasil yang diperoleh pada siklus I, belum dapat mencapai indikator kinerja penelitian yaitu $85 \%$. Sehingga, perlu diadakan perbaikan pada siklus II.

Pada siklus II, hasil observasi terhadap guru menunjukkan persentase $87,50 \%$, didukung dengan hasil wawancara terhadap guru yaitu $87 \%$. Hal tersebut menunjukkan bahwa guru dalam menerapkan model inkuiri terbimbing dengan multimedia sudah baik. Hanya terdapat sedikit kendala yang dialami guru dalam penerapan model tersebut. Siswa yang tuntas mencapai persentase $85,19 \%$. Hasil yang diperoleh pada siklus II sudah mencapai indikator kinerja penelitian yaitu $85 \%$. Namun, untuk semakin memantapkan hasil yang diperoleh maka penelitian dilanjutkan ke siklus III.

Pada siklus III, hasil observasi terhadap guru dalam menerapkan model menunjukkan persentase $95,14 \%$, didukung dengan hasil wawancara mencapai $92 \%$ 
adapun jumlah siswa yang tuntas mencapai 92,59\%. Hal tersebut menunjukkan bahwa guru sudah sangat baik dalam menerapkan langkah-langkah model inkuiri terbimbing dengan multimedia dalam pembelajaran. Hasil yang diperoleh pada siklus III sudah melebihi indikator kinerja penelitian sehingga penelitian ini dapat dihentikan.

Berdasarkan hasil dan pembahasan di atas dapat diketahui bahwa hasil observasi dan wawancara penerapan model inkuiri terbimbing dengan multimedia setiap siklusnya selalu meningkat. Dengan hasil penerapan model yang selalu meningkat tersebut membuat hasil belajar IPA siswa pada setiap siklus juga selalu meningkat. Hal ini sejalan dengan penelitian yang dilakukan oleh Pranowo, Parsaoran, dan Wawan (2017:4) terdapat perbedaan signifikan dalam peningkatan pemahaman konsep antara siswa yang memperoleh pembelajaran inkuiri terbimbing berbantuan multimedia dengan tanpa bantuan multimedia.

\section{SIMPULAN}

Simpulan : 1) Langkah-langkah penerapan model inkuiri terbimbing dengan multimedia meliputi: (a) orientasi dengan media power point text, (b) konseptualisasi dengan media power point text dan gambar/video, (c) investigasi dengan bantuan media kongkret, (d) menarik simpulan, dan (e) mendiskusikan hasil dengan power point text, yang dibuktikan dengan hasil observasi dan wawancara; dan 2) penerapan model inkuiri terbimbing dengan multimedia dapat meningkatkan hasil belajar IPA tema 6 tentang panas dan perpindahannya pada siswa kelas V SD Negeri 1 Kebulusan tahun ajaran 2018/2019 yang dibuktikan dengan peningkatan nilai tes evaluasi pada setiap siklus. Pada siklus I persentase ketuntasan mencapai $75,93 \%$, siklus II $85,19 \%$, dan siklus III 92,59\%.

\section{DAFTAR PUSTAKA}

Akbar, S. (2016). Implementasi Pembelajaran Tematik di Sekolah Dasar. Bandung: Rosadakarya Offset.

Amer, A. (2006). Reflection on Bloom's Revised Taxonomy. Electronic Journal of Research in Educational Psychology, 4 (1), 213-230.

Arikunto, S. (2013). Prosedur Penelitian: Suatu Pendekatan Praktik. Jakarta: Rineka Cipta.

Asyhar, R. (2012). Kreatif Mengembangkan Media Pembelajaran. Jakarta: Referensi Jakarta.

Aulia, E., F., Sri, P., \& Rudiana, A. (2017). The Effectiveness of Guided Inquiry-Based Learning Material on Students' Science Literacy Skills. Journal of Physics: Conference Series (Mathematics, Informatics, Science and Education International Conference), 947 (1), 1-7.

Husein, S., Lovy, H., \& Gunawan. (2015). Pengaruh Penggunaan Multimedia Interaktif Terhadap Penguasaan Konsep dan Keterampilan Berpikir Kritis Siswa pada Materi Suhu dan Kalor. Jurnal Pendidikan Fisika dan Teknologi, 1 (3), 221225.

Krathwohl, D., R. (2002). A Revisian of Bloom's Taxonomy: An Overview. Journal of Theory into Practice, 41 (2), 212-218.

Pedaste, M., et. al. (2015). Phases of Inquiry-based Learning: Definitions and the Inquiry Cycle. Journal Educational Research Review, 14, 47-61.

Pranowo, T., E., Parsaoran, S., Wawan S. (2017). Penerapan Multimedia dalam Pembelajaran IPA dengan Metode Inkuiri Terbimbing untuk Meningkatkan Pemahaman Konsep Perpindahan Kalor Siswa Kelas VII. Jurnal Wahana Pendidikan Fisika, 2 (1), 1-4.

Purwanto. (2014). Evaluasi Hasil Belajar. Yogyakarta: Pustaka Pelajar.

Sanjaya, W. (2012). Strategi Pembelajaran Berorientasi Standarproses Pendidikan. Jakarta: Kencana Prenada media. 
Volume 7 Nomor 3 Tahun 2019

Sayekti, I., C. (2015). Science Learning by Using Guided Inquiry Approach Through Experiment and Demonstration Method Viewed from Students' Scientific Attitudes. Proceeding of International Conference on Research, Implementation and Education of Mathematics and Sciences, hlm. 39-46, Universitas Negeri Yogyakarta, Yogyakarta.

Sugiyono. (2012). Metode Penelitian Kuantitatif, Kualitatif, dan R\&D. Bandung: Alfabeta.

Anam, K. (2016). Pembelajaran Berbasis Inkuiri Terbimbing: Metode dan Aplikasi. Yogyakarta: Pustaka Pelajar.

Wisudawati, A., W., \& Eka, S. (2015). Metodologi Pembelajaran IPA. Jakarta: Bumi Aksara.

Sobur, A. (2013). Psikologi Umum. Bandung: Pustaka Setia. 